\title{
An Investigation of the Effect of Curriculum-embedded Peer Mentoring on Student Learning in Two Undergraduate Mechanics Courses
}

\section{Dr. Molly McVey, University of Kansas}

Dr. Molly A. McVey is a post-doctoral teaching fellow at the University of Kansas School of Engineering where she works with faculty to incorporate evidence-based and student-centered teaching methods, and to research the impacts of changes made to teaching on student learning and success. Dr. McVey earned her Ph.D in Mechanical Engineering from the University of Kansas.

\section{Dr. Caroline R. Bennett P.E., University of Kansas}

Caroline is an Associate Professor in the KU Civil, Environmental, and Architectural Engineering department, with a specialty in structural engineering and bridge structures. She works closely with KU Engineering's post-doctoral Teaching Fellow and oversees the overall Engaged Learning Initiative in the School of Engineering. Caroline is responsible for overseeing KU Engineering's active-learning classroom design and usage, prioritizing course assignments in the active-learning classrooms, helping faculty to advance their pedagogy by incorporating best practices, and advancing implementation of studentcentered, active-learning approaches in the School of Engineering. Caroline is also active in contributing to university-level discussions in the area of course redesign, and has been closely involved with the KU Center for Teaching Excellence since 2006. She regularly teaches courses in bridge engineering, steel buildings, structural analysis, fatigue and fracture, elastic stability, and how to be an effective college teacher.

\section{Dr. Carl W. Luchies, University of Kansas \\ Prof. Rémy Lequesne}

Rémy D. Lequesne is Assistant Professor of Civil, Environmental and Architectural Engineering at the University of Kansas. His research interests include the design and behavior of reinforced concrete structures subjected to earthquake-induced ground shaking. His teaching interests include introductory mechanics, structural analysis, reinforced concrete design, and reinforced concrete behavior. 


\section{Peer Mentoring for All: Investigating the Feasibility of a Curricular-Embedded Peer Mentoring Structure}

\section{Introduction}

The benefits of peer mentoring in undergraduate STEM courses are well documented, and the literature suggests even more significant benefits to the mentors, compared to the mentees [1-3]. The School of Engineering at the University of Kansas has developed a peer-mentoring model called the Undergraduate Teaching Fellows Program, based on the Learning Assistant model [2]. Students who participate as mentors in this program reported an improved understanding of course content, more confidence in their academic and leadership abilities, and that they were more prepared to go into the workplace after their experience as a peer mentor in this program [4]. However, in this program, consistent with most peer mentoring programs, only the best students are selected for mentor roles. Thus, only the most academically-successful students gain the benefits of such an experience instead of all students.

Our team was interested in the feasibility of a peer-mentoring program in which all students in targeted courses act as mentors in some fashion. We piloted a peer-mentoring program in two departments: Civil, Environmental, and Architectural Engineering (CEAE), and Mechanical Engineering (ME). Within each department, peer-mentoring projects were embedded into courses in a similar program stream (i.e., upstream and downstream courses were related based on content). This pilot program focused on three types of mentoring projects: short video projects, a class project video, and design process mentoring. The short video projects involved students creating videos focused on technical skills fundamental to the upstream course, or on engineering identity/student success topics to share with the class directly upstream of them (prerequisite for the course they were in). Each instructor modified the mentoring assignment to investigate the feasibility and outcome of slightly different approaches. The class project video involved students creating a longer video detailing all they had learned about the field and profession of Architectural Engineering. The design process mentoring involved graduate students acting as consultants to undergraduate design students on their projects, meeting oneon-one to review their designs, ask questions, and provide resources and context. The goal of this work was to investigate the effectiveness and feasibility of these three projects as potential components of a curricular-embedded peer mentoring structure. This paper describes what we learned from this pilot project.

The primary questions investigated in this paper include: 1) Was the mentoring implementation effective to the students who made the video content and to students who engaged with the developed content? 2) What did students learn through the process? 3) Was there a different impact of the mentoring project on "average" students compared to "above average" students? 4) 
What recommendations can we provide for future implementation of such a program, based on this pilot study?

\section{Description of Tiered-Mentoring Projects}

Short video projects (CE 310, CE 562, ME 320, ME 682)

Course Descriptions: CE 310, "Strengths of Materials," is a required junior-level Civil Engineering (CE) course and is also required for Aerospace Engineering (AE) and Architectural Engineering (ARCE) majors. CE 562, "Design of Steel Structures," is a required senior-level course required for all CE and ARCE majors. ME 320, "Dynamics," is a required junior-level mechanical engineering (ME) course. ME 682, "System Dynamics and Control Systems," is a required senior-level ME course. In Fall 2017, enrollments for the courses were 31 students in CE 310, 38 students in CE 562, 58 students in ME 320, and 138 students in ME 628. Additionally, CE 461, "Structural Analysis," is a junior-level required CE course with 43 students enrolled in Fall 2017.

Table 1. Topics of Videos in Short Video Projects

\begin{tabular}{|c|c|c|}
\hline & Technical Topics & $\begin{array}{c}\text { Engineering Identity and Student } \\
\text { Success Topics }\end{array}$ \\
\hline \multirow{6}{*}{ CE 310} & Equilibrium & \\
\hline & Statics & \\
\hline & Trusses & \\
\hline & Reaction Forces & \\
\hline & Solving by Sections & \\
\hline & Joints & \\
\hline \multirow{4}{*}{ CE 562} & Conjugate Beam Method & \\
\hline & Virtual Work & \\
\hline & Force Method & \\
\hline & Influence Lines & \\
\hline \multirow{5}{*}{ ME 320} & Equilibrium & Internships \\
\hline & Reactions & Student Engineering Groups \\
\hline & Free Body Diagrams & Engineering Senior Projects \\
\hline & Moments & Tips for success in Engineering School \\
\hline & Vectors & Leadership Opportunities \\
\hline \multirow{7}{*}{ ME 682} & Linear Equations of Motion & \\
\hline & Rotational Equations of Motion & \\
\hline & Work and Energy & \\
\hline & Pipe Flow & \\
\hline & Conduction or Convection & \\
\hline & LaPlace Transforms & \\
\hline & ODE Solvers/Numerical Methods & \\
\hline
\end{tabular}


Assignment Description: Short video project assignments required students to develop short (approximately 2 to 6 minutes) videos to be shared with students in upstream courses. These short videos were developed by students in CE 310 (Strengths of Materials), CE 562 (Steel Design), ME 320 (Dynamics), and ME 682 (Control Systems). Students in CE 461 did not create content but had the option of viewing content created by CE 562 students. Three courses (CE 310, CE 562, and ME 682) required videos to be on a technical topic covered in the upstream course and fundamental to the work in the downstream course. The instructors chose and assigned topics to students. In ME 320, students could choose to make videos on either technical content, engineering identity, or student success topics. Table 1 provides examples of video topics for each course.

\section{Class Project Video: ARCE 101}

Course Description: ARCE 101, "Introduction to Architectural Engineering," is a required freshman-level course and had 50 students enrolled in the Fall 2017 semester.

Assignment Description: The class project video assignment required students to create a video (1) highlighting their path to the Architectural Engineering (ARCE) major, (2) explaining the components of earning an ARCE degree from KU, (3) describing what they learned over the semester about the field and profession, and (4) exciting their audience about the field and profession. The videos were to be designed with high school and middle school students as the intended audience. Students first submitted a project plan approximately five weeks before the final due date, and a draft of the submission due approximately 2 weeks prior to the final due date. The video lengths were set for between 12 and 15 minutes long and were developed and recorded individually. Detailed project requirements are provided in Table 2.

Table 2. Class Project Video Description

\begin{tabular}{|l|l|l|}
\hline \multicolumn{1}{|c|}{ Describe the ARCE Profession } & $\begin{array}{l}\text { Summarize Components of } \\
\text { ARCE Degree }\end{array}$ & $\begin{array}{l}\text { Your path to ARCE } \\
\text { and Experiences so } \\
\text { Far }\end{array}$ \\
\hline $\begin{array}{l}\text { What an ARCE is, and the difference } \\
\text { between an ARCE, architect, and civil } \\
\text { engineer. }\end{array}$ & $\begin{array}{l}\text { Describe what sorts of } \\
\text { courses are involved in the } \\
\text { ARCE curriculum. }\end{array}$ & $\begin{array}{l}\text { Describe your } \\
\text { background and what } \\
\text { drew you to ARCE. }\end{array}$ \\
\hline $\begin{array}{l}\text { How an ARCE can make the world a better } \\
\text { place and what an ARCE's career path can } \\
\text { look like. }\end{array}$ & $\begin{array}{l}\text { Describe the benefits of being } \\
\text { involved in undergraduate } \\
\text { organizations related to } \\
\text { ARCE. }\end{array}$ & $\begin{array}{l}\text { Describe the highlights } \\
\text { of your University } \\
\text { experience so far. }\end{array}$ \\
\hline $\begin{array}{l}\text { Summarize the topical areas ARCEs work } \\
\text { in, providing some details on each of the } \\
\text { sub-areas of ARCE. }\end{array}$ & $\begin{array}{l}\text { Describe which ARCE } \\
\text { student organizations are } \\
\text { available at the institution. }\end{array}$ & $\begin{array}{l}\text { Describe your favorite } \\
\text { classes. }\end{array}$ \\
\hline $\begin{array}{l}\text { Describe the types of questions and design } \\
\text { problems that practicing ARCEs regularly } \\
\text { deal with, and the types of tools that } \\
\text { ARCEs often employ in their work. }\end{array}$ & $\begin{array}{l}\text { Describe the role of } \\
\text { internships in gaining } \\
\text { practical experience. }\end{array}$ & $\begin{array}{l}\text { Describe why you chose } \\
\text { this particular } \\
\text { university. }\end{array}$ \\
\hline
\end{tabular}




\begin{tabular}{|l|l|l|}
\hline $\begin{array}{l}\text { Describe how an ARCE fits into the overall } \\
\text { design and construction process of the } \\
\text { building structure. }\end{array}$ & $\begin{array}{l}\text { Describe the support at the } \\
\text { institution that exists for } \\
\text { gaining an internship. }\end{array}$ & $\begin{array}{l}\text { Describe your career } \\
\text { goals after graduation. }\end{array}$ \\
\hline $\begin{array}{l}\text { Describe the role of professional licensure } \\
\text { in ARCE, and how that includes a strong } \\
\text { focus on engineering ethics and } \\
\text { professional development. }\end{array}$ & & $\begin{array}{l}\text { Describe what you are } \\
\text { most excited about } \\
\text { regarding studying } \\
\text { ARCE }\end{array}$ \\
\hline
\end{tabular}

\section{Design-Project Mentoring: (CE 562, CE 765)}

Course Descriptions: CE 562, "Design of Steel Structures," is a senior-level required course for CE and ARCE majors and 38 students were enrolled during Fall 2017. CE 765, "Advanced Steel Design," is a graduate-level course of which CE 562 is a pre-requisite, with 16 students enrolled during Fall 2017.

Assignment Description: This assignment required students in CE 765 to mentor students in CE 562 on the semester-long design project in CE 562. Graduate students were assigned to work with project design teams in CE 562 and were required to meet with their group for approximately 10 hours over the course of the semester, acting as a consultant.

\section{Evaluation of Project Effectiveness (Methods and Results)}

\section{Short Video Projects (CE 310, CE 562, ME 320, ME 682)}

Research Question 1: Was the mentoring implementation effective? Students in each course were asked to respond to survey questions asking multiple choice, yes/no, and Likert scale questions regarding their experience with the project. Multiple choice questions included questions about the videos they made (length, topic), their grade in the pre-requisite course, and their motivation level. Yes/No/Maybe questions included: "Do you have a deeper understanding of content related to the video you made," "Do you have more confidence in your understanding of the material," "Do you feel you have more expertise on the topic," "Do you feel that you provided useful information to students in the pre-requisite course," and "Do you feel more comfortable reaching out in a mentor role?" Survey results were analyzed for each course and then combined to be examined in aggregate. "Yes" and "maybe" responses were combined because not all courses offered the option of "maybe," but only offered "yes" or "no" as answers.

Students who viewed video content were asked to answer multiple choice survey questions, including: "How much time did you spend watching the videos," "How many different videos did you watch," "Which video topics were the most valuable to you," and we asked for the grade received in the prerequisite course. Only students who did watch videos were asked further survey questions which were Likert-scale questions asking about their level of agreement with the following statements: "The videos helped me to better understand the topic(s) in the videos," and "The videos created were relevant to me." They were also asked to rate video quality as Excellent, Satisfactory, or Poor. 


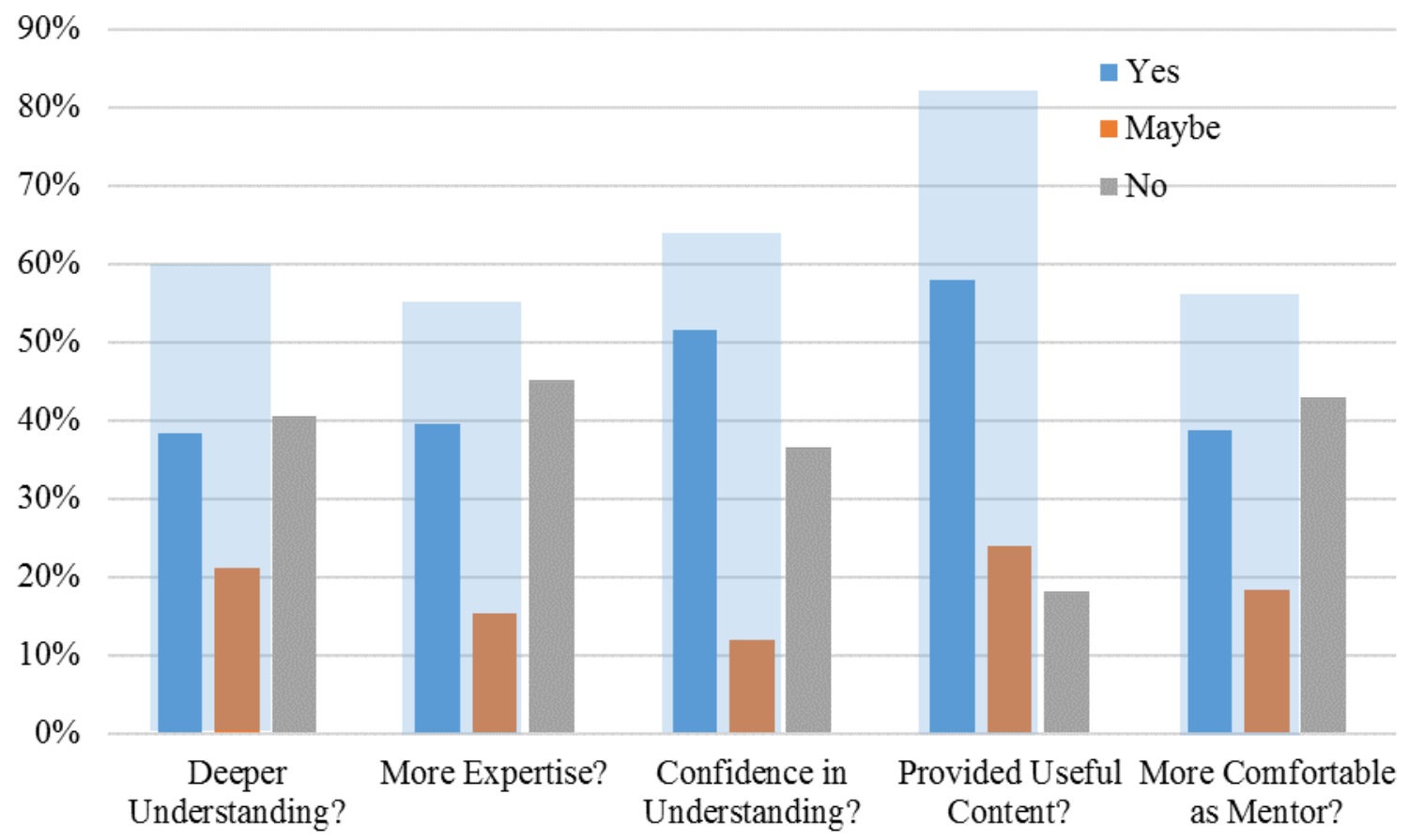

Figure 1. Feedback on effectiveness of short video projects from students who created content. Percentage of respondents who indicated "Yes," "Maybe," or "No" for survey questions. Light blue transparent box is the total of yes and maybe responses. $N=79$.

Survey response rate was 25/31 (81\%) for CE 310, $15 / 38$ (39\%) for CE 562, 20/58 (34\%) for ME 320, 19/138 (14\%) for ME 682, and 38/43 (88\%) for CE 461. In total, 118 survey responses from students were collected, with 79 responses from those who created content and 38 from those who watched content. The video projects were required, and approximately $91 \%$ of students participated in creating video content. Students who created content provided mixed feedback on the effectiveness of the project (Figure 1). For instance, $60 \%$ of survey respondents felt the project helped deepen their understanding, while $40 \%$ said it had no effect. Approximately $62 \%$ of respondents felt the project improved their confidence in their understanding. Slightly more than half of the respondents felt they had more expertise on the topic after this assignment. In aggregate, survey respondents felt that while they did provide useful information to upstream students $(81 \%)$, only $55 \%$ felt more comfortable in a mentor role.

Figure 2 shows the variability in survey results broken down by individual course. Students in CE 562 found the videos the most useful in deepening their understanding, with $86 \%$ answering "yes" or "maybe" to that question. Students in ME 682 answered the most positively (78\%) about feeling more comfortable as a mentor, and about having more expertise in their content area after the project (76\%). It should be noted, however, that ME 682 had the smallest fraction of students respond to the survey. Students in CE 310 responded the most positively (80\%) about having more confidence in their understanding. Students in ME 320 responded more negatively 
(50\% or more) than other classes with regard to all questions except the question about providing useful content.

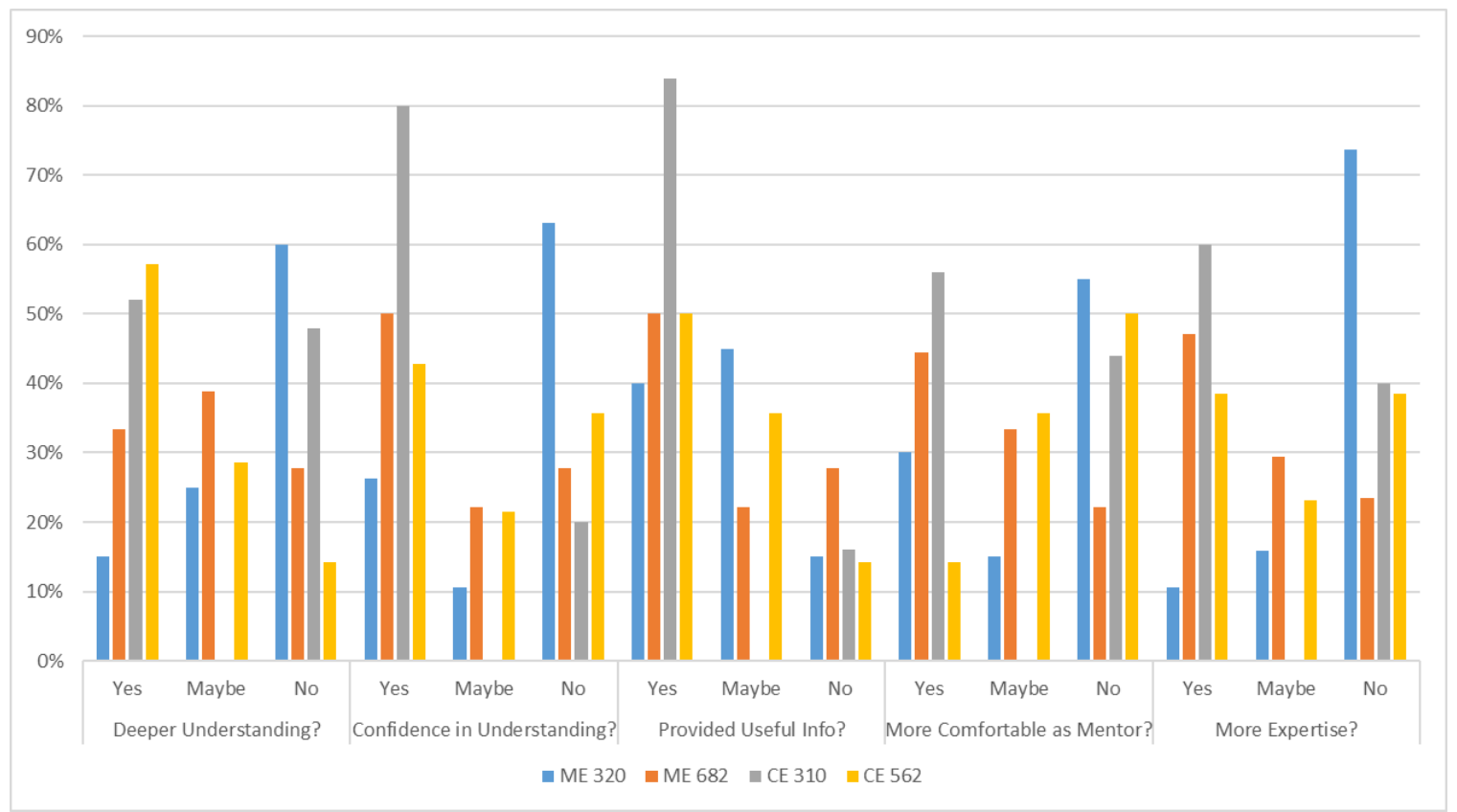

Figure 2. Survey results on effectiveness broken down by course. Percentage of respondents who indicated Yes/maybe" compared to "No" for each of the four courses involved, $N=79$ ).

One of the shortcomings in this first implementation of the project is that only one of the four courses actually shared content with the upstream course, and feedback from both students and faculty reflected that this was a major limitation to the effectiveness of this initial implementation. However, in the course that did share content (CE 562 shared with CE 461 "Structural Analysis"), we collected feedback on effectiveness from CE 461 students who engaged with the videos. Watching the videos was completely voluntary. The CE 461 instructor informed students that the videos were available and how to access them, but did not require students to watch the videos. $41 \%$ of respondents watched video(s) created by students in CE 562 , and of those who watched a video, $69 \%$ of them watched 2-3 different videos. The most viewed topics were the Conjugate Beam Method (60\% of viewers) and Influence Lines for Determinate Structures (24\% of viewers). Of those who watched at least one video, $57 \%$ either "agreed" or "strongly agreed" that the video helped improve their understanding, and 39\% "agreed" or "strongly agreed" that the video was relevant to what they were learning, and 82\% reported the videos were of either "satisfactory" or "excellent" quality.

Faculty were asked to measure the effectiveness of the project by approximating the percentage of videos that were of high enough quality to be utilized without further intervention. Across the four courses, an average of $40 \% \pm 27 \%$ of videos were considered to be of high enough quality to be utilized without further iteration. Course-specific results are in Figure 3. 


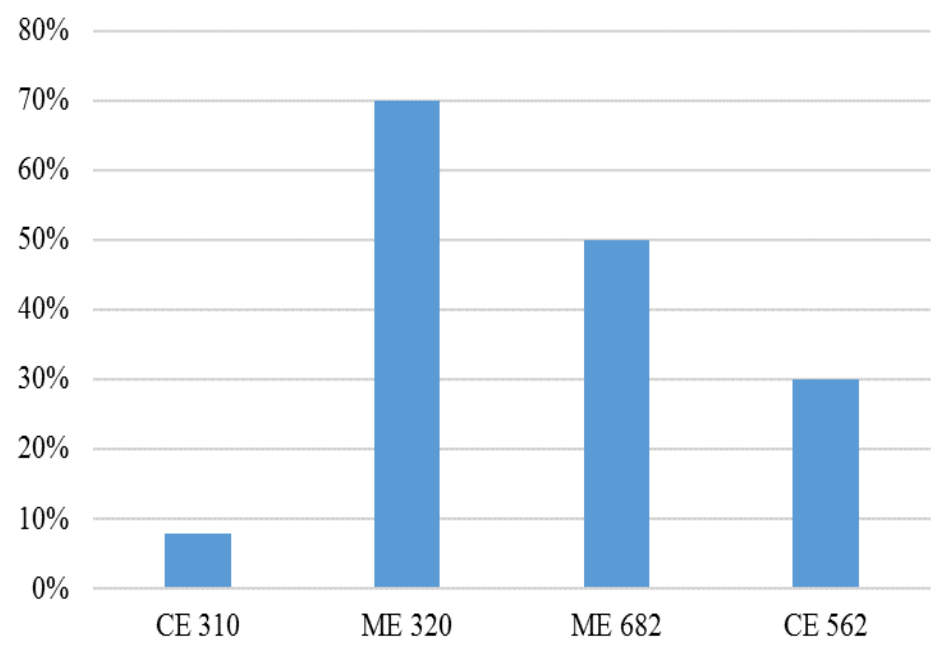

Figure 3. Percentage of videos created that were high enough quality to be utilized as is, as estimated by instructors of each course.

Research Question \#2: What did students learn through the video projects? The surveys given to students included open-ended questions asking them to reflect on the process. Questions included "What about the process of making the video had an impact on your understanding and/or confidence of/in the content," "What did you learn through the process of making the video," and "What recommendations do you have for making this video-creation assignment more meaningful?" These questions were a part of the same survey referred to in Research Question \#1 and had the same respondents. For analysis of open-ended questions, responses for each question from all courses were transcribed into a spreadsheet. Each response was recorded unless it was nearly identical to a previously recorded response. In that case, a mark indicating a repeat of that comment was noted. Next, common themes of responses were noted and responses were categorized into themes. The number of responses under each theme was counted and reported, and quotes from students that exemplify that theme were noted.

Responses to the question about what impacted their understanding or confidence fell into approximately five categories (Figure 4). "Teaching to others" (34\%) included responses indicating something about having to explain or present the content that was impactful. "More time with content" (28\%) included responses indicating that extra review, practicing, and extra time spent with the material was impactful. This category also included responses indicating extra review reinforced what they already knew. "Already comfortable" (15\%) included responses indicating nothing was impactful because they already fully understood the topic. "Nothing" (20\%) included responses indicating they learned nothing from the experience. "Other" included responses that were only mentioned once and did not fit any other category. 
Responses to the question about what they learned through this process fell into 7 categories (Figure 4). "Appreciation for teaching" (21\%) included responses indicating they learned something about how to teach, the requirements of teaching, or about liking or disliking teaching. "Delivery technique" (12\%) included responses indicating they learned something about effectively delivering content, "Content specific understanding" (12\%) included responses indicating they learned something related to the content of their video. "How I learn" (9\%) included responses indicating they learned something about their own learning. "Like/dislike of topic or technology" (7\%) included responses about preferences specific to the technology used or topic of the video. "Nothing" (7\%) referred to responses indicating they learned nothing from the experience. Finally, "Confidence" (3.5\%) included responses indicating they learned something about their confidence in the material. Examples of student quotes and responses are given in Table 3.

What Had an Impact on Understanding and/or Confidence?

What Did you Learn Through This Process?
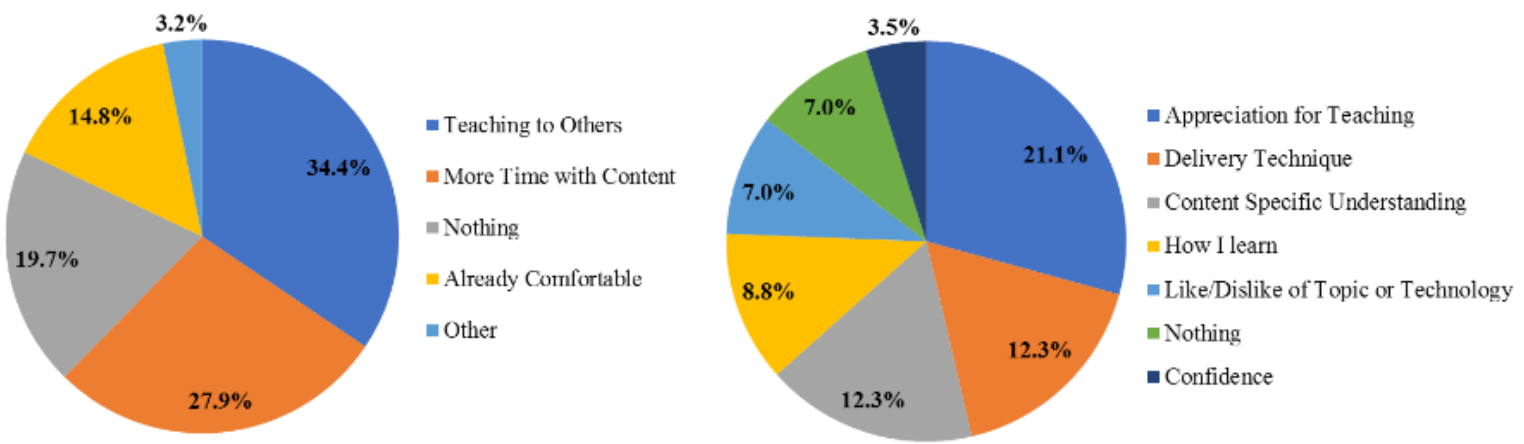

Figure 4. Percentage of responses in each categoery of open-ended survey question responses, $N=79$. 
Table 3. Sample of Student Comments

\begin{tabular}{|c|c|}
\hline $\begin{array}{l}\text { "What was it about the process of making the } \\
\text { videos that had an impact on your } \\
\text { understanding and/or confidence of the topic?" }\end{array}$ & "What did you learn through this process?" \\
\hline $\begin{array}{l}\text { "I had to formulate my own way of explaining static } \\
\text { equilibrium, which made me think deeper on the } \\
\text { topic (CE 310)." }\end{array}$ & $\begin{array}{l}\text { "I'm not the best at making a creative video, but it made me } \\
\text { sit down and learn material in a different way than just } \\
\text { doing homework problems (CE 310)." }\end{array}$ \\
\hline $\begin{array}{l}\text { "It made me remember the approaches I took which } \\
\text { was a good review for the current problems I deal } \\
\text { with (CE 310)." }\end{array}$ & $\begin{array}{l}\text { "I learned how to break down a complex problem into easy } \\
\text { to understand parts (CE 310)." }\end{array}$ \\
\hline $\begin{array}{l}\text { "I unfortunately received a low grade in Statics. } \\
\text { However, my understanding of the topics covered in } \\
\text { statics was dramatically improved in Mechanics of } \\
\text { Materials. Through the creation of this video, I have } \\
\text { my first real indication of how much my } \\
\text { understanding of the material has improved. (ME } \\
\text { 320)." }\end{array}$ & $\begin{array}{l}\text { "Explaining things out loud is useful for learning (CE } \\
\text { 310)." }\end{array}$ \\
\hline $\begin{array}{l}\text { "Organizing my thoughts: this project allowed me to } \\
\text { identify key components of my previous internship } \\
\text { that I want to emphasize when applying for my next } \\
\text { internship. (ME 320)." }\end{array}$ & $\begin{array}{l}\text { "I learned how to operate the Elmo machines in the } \\
\text { classrooms (ME 320)." } \\
\text { "I liked the voice-over integration the program } \\
\text { (Voicethread) utilized. (ME 320)." }\end{array}$ \\
\hline $\begin{array}{l}\text { "If you want to teach someone something... you must } \\
\text { have a very in depth knowledge of the topic in order } \\
\text { to explain through analogy and layman terms. So } \\
\text { yes, I do have a deeper understanding because I felt I } \\
\text { had to research the topic more in order to } \\
\text { adequately explain the subject to others. (CE 562)" }\end{array}$ & $\begin{array}{l}\text { "That teaching is a lot harder than it looks, and it takes } \\
\text { more preparation than I anticipated (ME 562)." }\end{array}$ \\
\hline $\begin{array}{l}\text { "Having to go back and learn the material causes } \\
\text { someone to go back and think about how they were } \\
\text { able to understand it the first time. (CE 562)" }\end{array}$ & $\begin{array}{l}\text { "I realized how easy it is to forget what was learned in } \\
\text { previous semesters, but that it could easily come back if } \\
\text { needed (CE 562)." }\end{array}$ \\
\hline $\begin{array}{l}\text { "The researching part had a large impact on my } \\
\text { understanding of the topic... but the translation of } \\
\text { that knowledge into a script and then presenting it } \\
\text { felt more important. It not only played a large role } \\
\text { in the development of confidence, it further } \\
\text { increased my understanding. It forces you to } \\
\text { understand it on a deep enough level for both } \\
\text { application and education. (CE 562)" }\end{array}$ & $\begin{array}{l}\text { "It helped me remember that I love connecting concepts and } \\
\text { showing how they are related, and being challenged to do so } \\
\text { in a simple and easily understood manner (ME 682)." }\end{array}$ \\
\hline $\begin{array}{l}\text { "I wanted to make sure our group was explaining the } \\
\text { topic correctly so I reviewed my notes from ME } 508 \\
\text { and ...practiced a few problems so I understood } \\
\text { completely (ME682)." }\end{array}$ & $\begin{array}{l}\text { "I learned that it is enjoyable to be a teacher explaining to } \\
\text { people what you know and help them get some ideas (ME } \\
682) . "\end{array}$ \\
\hline
\end{tabular}


Research Question \#3: Was there a different impact of the mentoring project on "average" students compared to "above average" students? After examining the overall survey results, we separated the responses based on grades received in pre-requisite courses. We assigned values of $1=$ No, $2=$ Maybe, and $3=$ Yes to the survey question answers and analyzed the average scores for each question between the two groups (A/B in pre-requisite course vs. $\mathrm{C}$ or below in prerequisite course). A $t$-test was used to test for statistical significance. The results (Figure 5) showed that students who came into the class with a $\mathrm{C}$ or below felt that the tiered mentoring project gave them more expertise $(\mathrm{p}=.02)$ and more confidence $(\mathrm{p}=.01)$ in the topics they worked on, compared to students who came into the class with As or Bs.

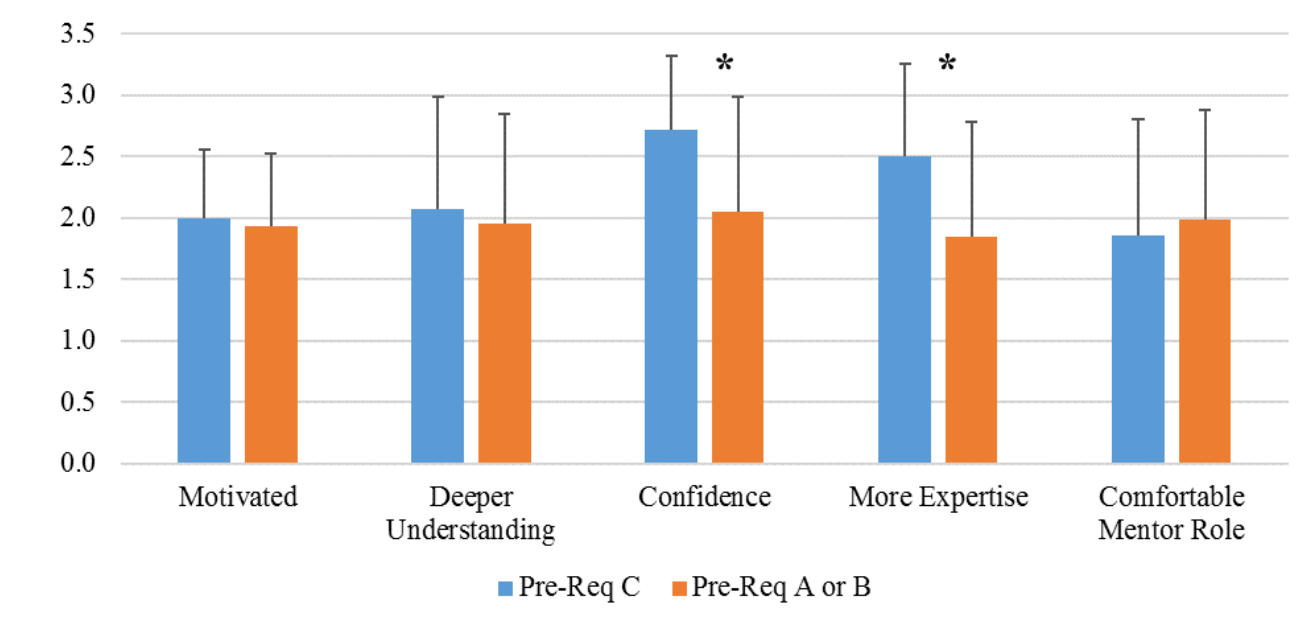

Figure 5. Survey responses based on pre-requisite course grade (Blue $=C$ or below in pre-requisite course $(N=14$, Orange $=A$ or $B$ in pre-requisite course $(N=65)$.

Research Question \#4: What recommendations do we have based on this pilot study for future implementation of such a program? Open-ended survey questions from students and faculty asking for their recommendations to make this project more effective were analyzed similarly to the open-ended questions in Research Question \#2. The most important recommendation is that developing an authentic connection between students creating the content and those utilizing the content is crucial. More planning and coordination is necessary to make the connection with the upstream students, and to have the timing of the assignment align with when it will be most useful for students to watch the content. Other feasibility findings included the need for a more streamlined way of creating, editing, and posting videos. Three of the four courses used Voicethread to share the videos, and there was a learning curve associated with the software. Other considerations mentioned by faculty included experiencing pushback from the students, the timing of the assignment (seemed to be more effective earlier in the semester), and they were not sure the assignment clearly aligned with course learning objectives. The most common recommendations from students on making this activity more effective was to change aspects of project facilitation (24\%). Responses in this category included making the project worth more points, doing the project at a different point in the semester, changes to specifics of the 
assignment such as whether it is done individually or in groups, and the length of videos. Other common themes relating to providing more guidelines $(21 \%)$, and having a connection with the audience $(21 \%)$. The distribution of recommendations from students are shown in Figure 6.

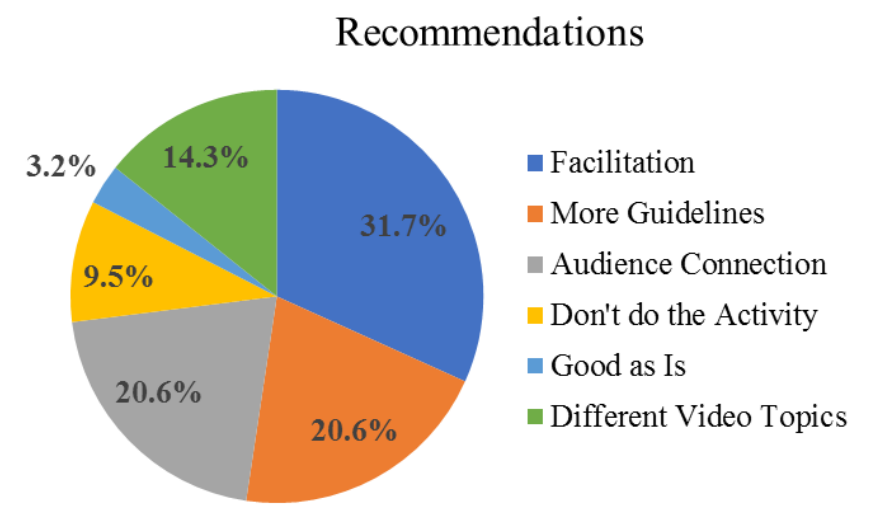

Figure 6. Recommendations from students on making this activity more effective. Percentages of total responses in each category $(N=79)$.

\section{Class Project Video: ARCE 101}

Research Question \#1: Was the mentoring implementation effective? Students in ARCE 101 were asked to respond to multiple choice and Yes/No/Maybe survey questions regarding their experience with the project. Multiple choice questions included questions about the time spent on the project, their motivation level, and their expected grade in the course. Yes/No/Maybe questions asked about the effectiveness of the project ("Do you have a deeper understanding of the ARCE," and "Do you have increased confidence in your understanding of ARCE?").

Survey response rate was 34/50 (68\%). A summary of survey responses are presented in Figure 7. The majority of respondents reported spending 3-5 hours $(68 \%)$ or 6-8 hours $(21 \%)$ on the project. Students reported being either "very motivated" (29\%) or "somewhat motivated" (71\%) to do an excellent job on the project. Overall, feedback was very positive on the effectiveness of the project at deepening students' understanding and confidence in their understanding of the ARCE major and profession. Approximately $82 \%$ of students felt that, due to the video project, they had a deeper understanding of ARCE and more confidence in their understanding of ARCE (Figure 7). Respondents also felt positively that they created meaningful content for other students $(91 \%)$, and feeling more comfortable as a mentor due to this project $(71 \%)$. 


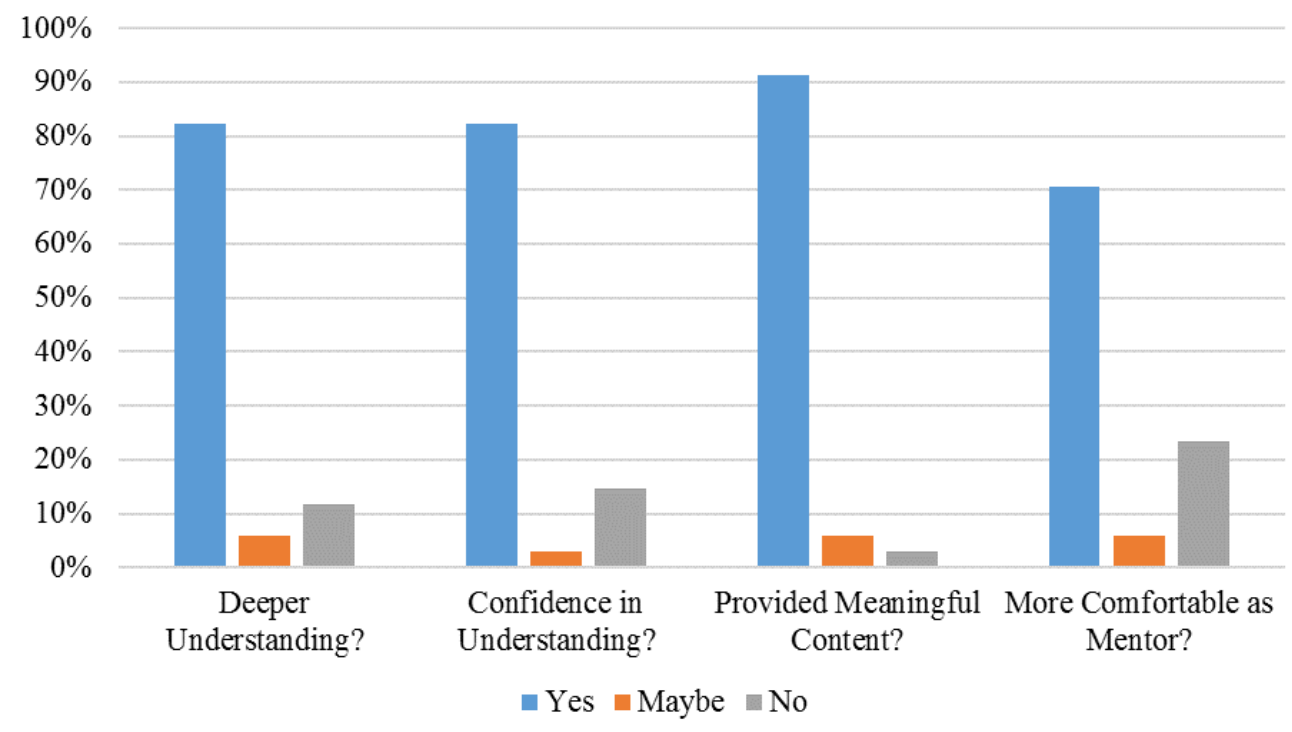

Figure 7. Feedback on effectiveness of short video projects from students who created content.

Percentage of respondents who indicated "Yes", "Maybe", and "No" for survey questions, $N=34$.

Research Question \#2: What did students learn through the video projects? The surveys given to students included open-ended questions asking students to reflect on the process. Open-ended questions included "What was it about the process of making the video that had an impact on your understanding and/or confidence," "What did you learn through the process of making the video," and "What recommendations do you have for making this assignment more meaningful?" Answers for each question were transcribed into a spreadsheet, in the same manner as described for the short video project analyses.

Responses to the question about what had an impact on their understanding or confidence in the content fell into approximately six categories (see Figure 8). "Researching ARCE" (33\%) included responses indicating it was something about having to do research on their own that had an impact. "Explaining to Others" (20\%) included responses indicating having to explain their knowledge had an impact. "Organizing Knowledge" (18\%) included responses indicating that it was organizing what they had learned that was helpful. "Reviewing and Reflecting" (13\%) included responses indicating having to think more about what they learned, how it all fits together, and how they feel about what they learned was impactful. "Presenting what was Interesting" (10\%) included responses indicating it was being able to talk about what excited them or what they wanted to know more about that was impactful. Other responses included learning technical skills related to making videos, learning the software, and seeing what others had created. 
What Did You Learn Through This Process?

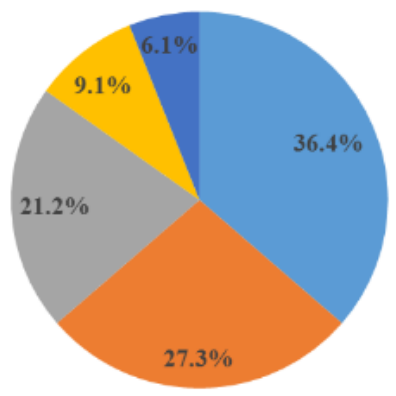

= Technical/Delivery

= ARCE Discipline/Major/Career

= More Passionate about ARCE

m Confidence in Career Path n How I Learn/study skills
What Had an Impact on Your Understanding?

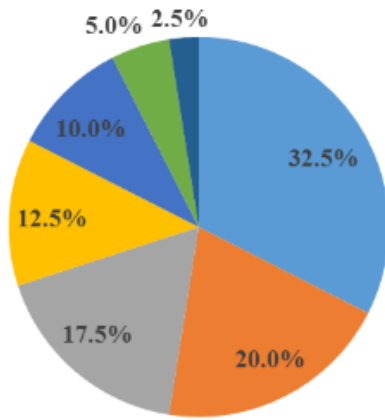

- Researching ARCE

Explaining to Others

n Organizing Knowledge

neviewing and Reflecting

a Presenting what was Interesting to me

a Technical Related to Videos

- Watching Other Videos

Figure 8. Percentage of responses in each category of open-ended survey question responses, $N=34$.

Responses to the question about what they learned through this process fell into five categories (see Figure 8). "Technical/Delivery" (36\%) included responses relating to how to use software or hardware for video creation or learning something about effective delivery. "ARCE Discipline/Major/Career" (27\%) included responses indicating they learned more about the ARCE field. "More Passionate about ARCE" (21\%) included responses indicating they had a newfound or increased level of excitement and/or passion for ARCE as their chosen pathway. "Confidence in Career Path" (9\%) included responses indicating they are more confident now than before on their choice of ARCE as a career." "How I learn/study skills" (6\%) included responses indicating the students learned something about how they learn or how they could do better at learning content. Examples of student quotes are given in Table 4. 
Table 4. Sample of student responses to open-ended survey questions for short video projects.

\section{"What was it about the process of making the videos that had an impact on your understanding and/or confidence of the topic?"}

\begin{tabular}{|c|c|}
\hline $\begin{array}{c}\text { "The research of the project and organizing } \\
\text { everything into a rough draft/plan." }\end{array}$ & $\begin{array}{l}\text { "I learned about some of the resources KU offers } \\
\text { because I filmed my video in Studio K in Watson } \\
\text { Library. I also cleared up confusion I had about } \\
\text { ARCE vs architecture vs civil engineering vs } \\
\text { construction management etc." }\end{array}$ \\
\hline $\begin{array}{l}\text { "Revisiting and revitalizing my memory and } \\
\text { knowledge of what was learned in the class." }\end{array}$ & $\begin{array}{l}\text { "I learned that just like this project, ARCE is a } \\
\text { process. It takes many different people in different } \\
\text { roles to come together and work as a team in order } \\
\text { to design and construct a building." }\end{array}$ \\
\hline $\begin{array}{c}\text { "Having to come up with my own words and } \\
\text { definitions for everything definitely helped hone } \\
\text { and develop my understanding and confidence on } \\
\text { the subject." }\end{array}$ & $\begin{array}{c}\text { "I am a lot more excited for my major than I } \\
\text { thought" }\end{array}$ \\
\hline $\begin{array}{l}\text { "It was the connecting the information we learned } \\
\text { in class and making a video based on that. As well } \\
\text { as the research I put in getting more info for the } \\
\text { project that would be good. Ifelt like I had } \\
\text { conmand of the material." }\end{array}$ & $\begin{array}{l}\text { "I learned about how passionate I actually am } \\
\text { about the topic. Doing this project made me } \\
\text { excited for what's to come." }\end{array}$ \\
\hline $\begin{array}{l}\text { "The video allowed me to bring everything full } \\
\text { circle, and allowed me to review my understanding } \\
\text { that I had gained throughout the semester." }\end{array}$ & $\begin{array}{l}\text { "One of the things Ilearned during the video and } \\
\text { through the class was just how broad ARCE is. } \\
\text { Coming in, I thought that all ARCE's were the } \\
\text { same and that just is not the case with all the } \\
\text { different sub-disciplines." }\end{array}$ \\
\hline $\begin{array}{c}\text { "Researching and then synthesizing that research } \\
\text { to put it into a video." }\end{array}$ & $\begin{array}{c}\text { "I learned how to use voicethread and I also } \\
\text { learned how to explain what an ArchE is to the } \\
\text { average person." }\end{array}$ \\
\hline $\begin{array}{c}\text { "I learned how to edit and create videos on my } \\
\text { phone. This was a new understanding." }\end{array}$ & $\begin{array}{l}\text { "I learned that being an engineer doesn't mean } \\
\text { you are tied down to doing one thing for your life. } \\
\text { There are a lot different things I can do and } \\
\text { because of that it makes me really excited to get } \\
\text { out into the field and do the work." }\end{array}$ \\
\hline $\begin{array}{l}\text { "I had to be sure that what I was saying in the } \\
\text { video was factual and that meant doing research } \\
\text { and looking back to the topics covered in class." }\end{array}$ & $\begin{array}{l}\text { "I learn that architectual engineering alot of } \\
\text { branches and you can-be specific in what you love } \\
\text { more after graduating and that was surprising for } \\
\text { me and give me motivation to keep going" }\end{array}$ \\
\hline
\end{tabular}

\section{"What did you le arn through this process?"}


Research Question \#4: What recommendations do we have based on this pilot study for future implementation of such a program? Open-ended survey questions from students and faculty asking for their recommendations to make this project more effective were analyzed similarly to the open-ended questions in Research Question \#2. The recommendations from students (see Figure 9) fit into four categories. "Change Assignment Details" (35\%) refers to responses indicating they would like some detail of the project changed. For instance, they would like to work in pairs instead of individually, or they would prefer to talk about a different topic. "More Guidelines" (17\%) includes responses asking for more guidelines and/or feedback on the project. "Give to a Real Audience" (17\%) includes responses that either indicate a desire to give their presentation in real-time to an audience, or who would want to send their video to someone specific. "Different Software" (14\%) indicates they didn't like the software (Voicethread) used for this activity. $17 \%$ of students liked the project as-is and did not have suggestions for improvement.

\section{Recommendations}

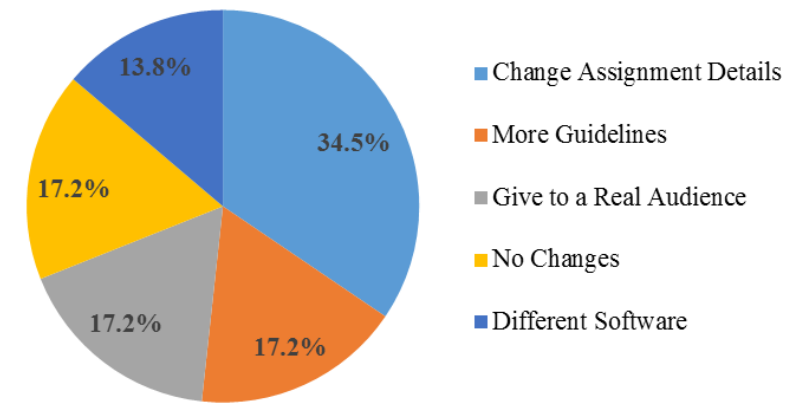

Figure 9. Recommendations from students on making this activity more effective. Percentages of total responses in each category $(N=34)$.

The instructor of ARCE 101 thought the project was effective because "it allowed them to synthesize what they had learned and to think critically about what it means to be an ARCE." The instructor also highlighted the research that students had to do on the various sub-disciplines of ARCE as being important. These points echo the student feedback on what was impactful about this project. Recommendations for implementation of this project again included more clearly defining the expectations and scaffolding students to develop more polished final products. Similar to the short video projects, this pilot implementation did not close the loop and actually have students deliver or present their final projects, which we believe to ultimately be an important part of this process.

\section{Design-Project Mentoring: (CE 562, CE 765)}

Research Question \#1: Was the mentoring implementation effective? Students in each course were asked to respond to survey questions asking multiple choice and Likert scale questions regarding their experience with the project. Students in CE 562 (the students being mentored) were asked how much time they spent meeting with graduate students and they were asked to 
indicate their level of agreement with questions related to the effectiveness of the project. Questions for students in CE 765 (the graduate students doing the mentoring) included "Do you have a deeper understanding of content,", "Do you have more confidence in your abilities," "Do you feel more connected to students and faculty in the department," "Do you feel more prepared to contribute in the workplace," "Do you feel as though your communication skills have improved," and "Do you think meeting with the students in CE 562 was worthwhile to you?"

Survey response rates were 15/38 (39\%) for CE 562 and 14/16 (88\%) for CE 765. Students in CE 562 reported spending between 2-10 hours meeting with graduate students from CE 765 . A majority of CE 562 respondents "agreed" (27\%) or "strongly agreed" (53\%) that meeting with the graduate students was an effective use of their time. $7 \%$ of respondents were neutral about the meetings, and $13 \%$ "strongly disagreed" that they were an effective use of time. Responses to the question "I was able to do higher quality work because of my meetings with the graduate students" were very positive as well, with 40\% indicating they "strongly agree", $40 \%$ "agree", 13\% "neutral", and 7\% "strongly disagree." Students in CE 765 reported spending a wide range of time spent meeting with the CE 562 students: $36 \%$ of respondents reported spending 2-4 hours, 43\% 5-7 hours, 7\% 8-10 hours, and 14\% reported spending more than 10 hours. Students in CE 765 responded most positively to feeling as though this activity made them feel more connected to the students and faculty in the department (71\% agreed or strongly agreed) and to feeling as though the mentoring was a worthwhile activity (65\% agreed or strongly agreed). A

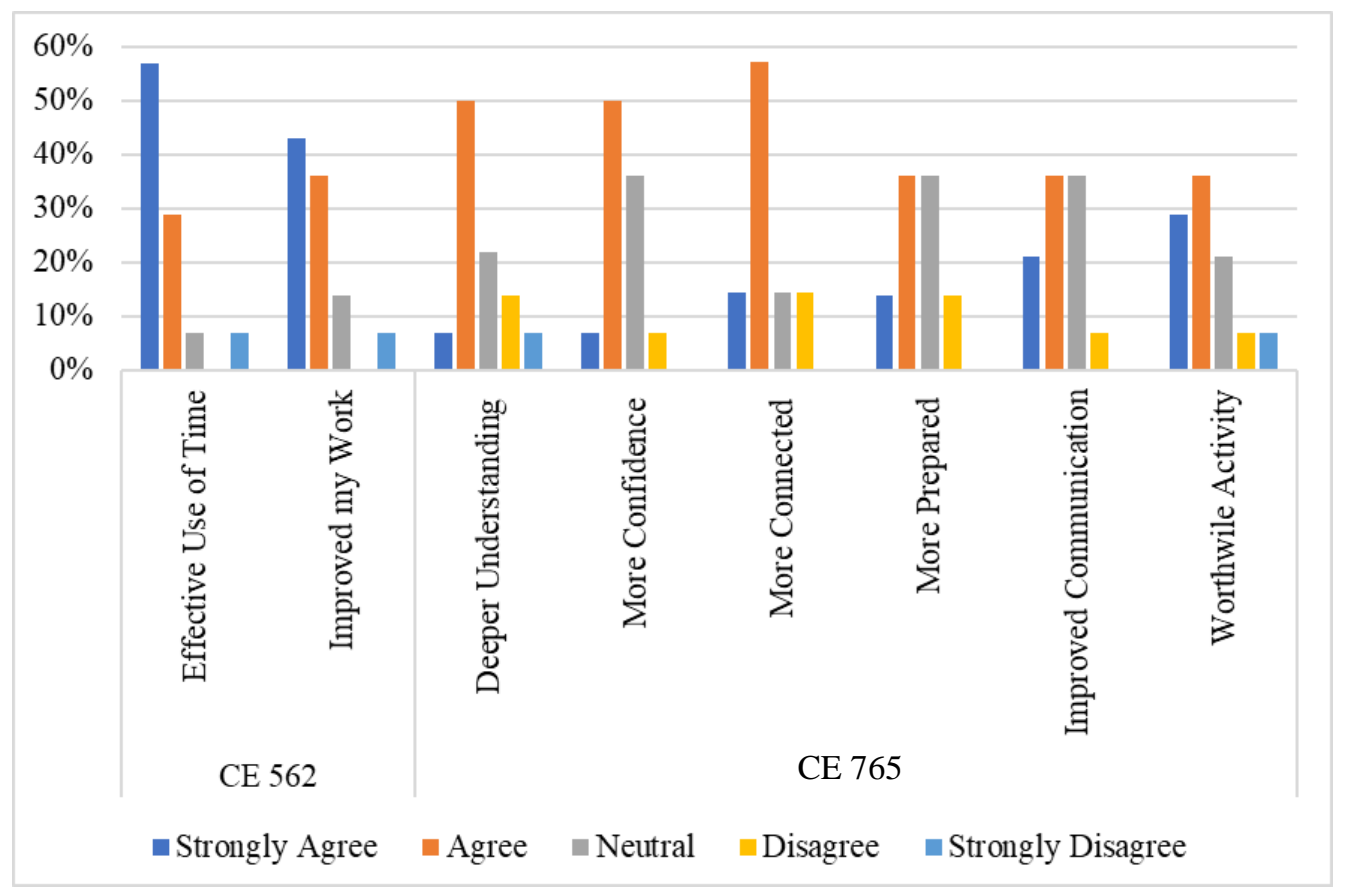

Figure 10. Survey results on effectiveness of design project mentoring. Percentage of respondents who indicated the given levels of agreement with statements for CE 562 students who were mentored $(N=15)$ and CE 765 students who were doing the mentoring $(N=14)$. 
majority also felt the mentoring activity gave them a deeper understanding and more confidence in their knowledge (57\% agreed or strongly agreed). Complete results are shown in Figure 10.

Research Question \#2: What did students learn through the video projects? The surveys given to students included open-ended questions, asking students to reflect on the process. Open-ended questions for CE 562 students asked "What is one thing you learned through meetings with the graduate students," and CE 765 students were asked "What is one thing you liked about this activity?" Open-ended responses were recorded and categorized based on emergent themes.

Response rates for the open-ended questions were 15/38 (39\%) for CE 562 and 8/16 (50\%) for CE 765. Responses for "What is one thing you learned" in CE 562 fell into primarily two categories: something specific about design (50\%) (e.g., constructibilty, beam selection, connections, etc.), or learning about the design process as a whole (31\%). Other responses mentioned learning the importance of using spreadsheets, learning that graduate students are busy, and "nothing." Responses for "What is one thing you liked about this activity" for CE 765 students fell into primarily two categories: learning/reviewing knowledge (50\%), and working with undergraduates $(25 \%)$. Other responses included "communicating industry knowledge."

Research Question \#4: What recommendations can we provide based on this pilot study for future implementation of such a program? Open-ended survey questions from students and faculty in CE 562 and CE 765 asking for their recommendations to make this project more effective were analyzed similarly to the open-ended questions in Research Question \#2. The recommendations from students in both courses were combined (see Figure 11) and fit into four categories. "Logistics" (31\%) included responses based on when/where to meet and how to facilitate the meetings. "More direction/oversight" (27\%) included responses suggesting either more guidelines for the students in CE 562 or more oversight of the students in CE 765 to make sure they were doing a good job of mentoring. "Meet earlier in the semester" $(23 \%)$ included responses who suggested starting the project and/or meetings sooner. $15 \%$ of respondents thought the project was good as-is, and $4 \%$ thought the graduate students should attend the final presentation to see the final product of the students in CE 562. 
Recommendations

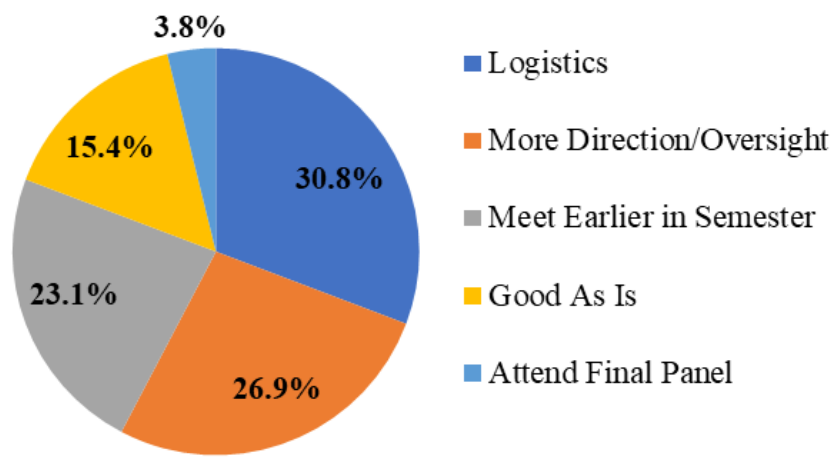

Figure 11. Recommendations from students on making this activity more effective. Percentages of total responses in each category $(N=23)$.

\section{Discussion}

This pilot project was designed to examine the effectiveness and feasibility of implementing curriculum-embedded tiered-mentoring projects that allow all students in a course to participate. One major outcome is the importance of connection. Due to the pilot nature of these projects, not all students had the opportunity to interact or share their content with other students in an authentic manner. Both students and faculty commented on the importance of 'closing the loop'. However, even given this limitation, feedback from students was positive in most of the classes, and this process allowed us to gain valuable feedback on how to improve the effectiveness. Finally, these projects did show a potential to more positively impact $\mathrm{C}$ or below students, compared to A and B students only. This is an encouraging finding because it supports the motivation behind this pilot project to extend the benefits of peer mentoring to all students. Future work includes coordinating between courses to share content and to foster a better connection between students in the upstream and downstream courses.

\section{References}

[1] K. E. Amaral and M. Vala, "What teaching teaches: Mentoring and the performance gains of mentors," J. Chem. Educ, vol. 86, no. 5, p. 630, 2009.

[2] V. Otero, S. Pollock, and N. Finkelstein, "A physics department's role in preparing physics teachers: The Colorado learning assistant model," American Journal of Physics, vol. 78, no. 11, pp. 1218-1224, 2010.

[3] E. W. Close, J. Conn, and H. G. Close, "Becoming physics people: Development of integrated physics identity through the Learning Assistant experience," Physical Review Physics Education Research, vol. 12, no. 1, p. 010109, 2016.

[4] M. A. McVey, C. A. Bennett, J. H. Kim, and A. Self, "Impact of Undergraduate Teaching Fellows Embedded in Key Undergraduate Engineering Courses," presented at the 2017 ASEE Annual Conference \& Exposition, Columbus, OH, 6/28/2017, 2017. Available: https://peer.asee.org/28471 